\title{
PLN vs Energi Terbarukan: Peraturan Menteri ESDM Terkait Penggunaan Sistem Pembangkit Listrik Tenaga Surya Atap
}

\author{
Suci Modjo ${ }^{1}$
}

\begin{abstract}
Abstrak
Mengingat keadaan iklim tanpa musim yang menyediakan sinar matahari sepanjang tahun dan tipe perumahan yang umumnya melekat dengan tanah, penggunaan panel surya atap sebagai sumber energi alternatif harusnya digalakkan di Indonesia. Di antara pelbagai cara pemberian insentif penggunaan panel surya adalah melalui pengurangan halangan peraturan dalam tahap instalasi, dan pembelian kelebihan tenaga oleh Pemerintah dengan harga yang diunggulkan. Tulisan ini membahas Peraturan Menteri Energi dan Sumber Daya Mineral terkait Penggunaan Sistem Pembangkit Listrik Tenaga Surya Atap oleh Konsumen PT Perusahaan Listrik Negara (Persero). Peraturan ini memberi kewenangan yang luas kepada PLN, dari izin instalasi hingga pembelian kelebihan tenaga dengan potongan harga, yang secara praktis menempatkan masyarakat dan kelestarian lingkungan hidup pada posisi yang lebih lemah dibanding dengan pembangkit listrik komersial. Pemberian kewenangan yang luas kepada PLN tersebut merupakan pelanggaran konstitusi, bertentangan dengan komitmen Pemerintah untuk meningkatkan diversifikasi sumber listrik, dan secara umum kontra-produktif terhadap upaya pengurangan emisi dari pembangkit listrik.
\end{abstract}

Kata kunci: PLN, ESDM, PLTS

\section{Abstract}

Considering its non-seasonal climate providing year-round sunshine and the widespread use of landed properties, the use of rooftop solar panels as an alternative source of energy should be strongly encouraged in Indonesia. Amongst the ways to incentivise the use of solar panels are to lower regulatory barriers to installing them, and to guarantee the purchase of excess electricity by the Government at preferable rates. This paper discusses the Minister of Energy and Mineral Resources Regulation related to The Use of Rooftop Solar Power Producer by PT Perusahaan Listrik Negara. This regulation gives PLN a wide authority, from licencing installation to purchasing excess power at a discount, practically putting community and environmental sustainability at a disadvantage compared to commercial power producers. Providing such sweeping authority to PLN is unconstitutional, contrary to the commitment by the Government to diversify power sources, and generally counter-productive towards the effort to reduce emission from power plants.

Keywords: PLN, PLTS, MEMR

\footnotetext{
${ }^{1}$ Penulis merupakan advokat di bidang energi dan infrastruktur.
} 


\section{Pendahuluan}

Tenaga surya merupakan sumber energi terbarukan yang sungguh ramah lingkungan. Pembangkit Listrik Tenaga Surya (PLTS) dengan model paling sederhana dibangun dengan melekatkan panel fotovoltaik pada atap rumah dan bangunan, yang menangkap paparan sinar matahari sepanjang hari dan menggunakannya untuk memenuhi kebutuhan listrik rumah atau bangunan yang bersangkutan, menjadikan PLTS sebagai sumber energi yang efisien dan ramah lingkungan. Namun demikian, pengembangan PLTS sebagai sumber energi untuk kepentingan umum belum jamak dilakukan baik oleh Pemerintah (melalui PT Perusahaan Listrik Negara (PLN) ataupun swasta (IPP) dengan alasan mahalnya nilai investasi yang dibutuhkan menjadikan daya saing PLTS sangat lemah dibandingkan pembangkit bertenaga lain. Sayangnya, kebijakan terkait tidak mendukung keekonomian PLTS yang diinisiasi masyarakat dan kalangan bisnis dan malah semakin mengurangi potensi daya saing PLTS.

Penggunaan panel surya fotovoltaik sudah populer di berbagai kalangan seperti perumahan (sejak penggunaan awalnya sebagai pemanas air), gedung pemerintah dan fasilitas umum², hingga bangunan milik swasta yang mengejar penghematan rekening listrik dan sertifikasi sebagai green building ${ }^{3}$. Potensi penggunaan tenaga surya sebagai sumber pembangkit listrik di Indonesia sangatlah besar mengingat letak geografis kepulauan di garis khatulistiwa yang menjamin sinar matahari sepanjang tahun. ${ }^{4}$ Dibandingkan dengan Jerman, misalnya, salah satu negara di Eropa dengan iklim empat musim yang membatasi paparan surya mereka, Indonesia berpotensi menghasilkan 10 kali lipat tenaga listrik berbasis surya. ${ }^{5}$ Ditambah lagi dengan tipe perumahan Indonesia yang umumnya melekat dengan tanah

${ }^{2}$ MTH, "Pasang PLTS Atap, Tagihan Listrik Lebih Hemat," https://kominfo.go.id/index.php/ content/detail/20547/pasang-plts-atap-tagihan-listrik-lebih-hemat/0/artikel_gpr, diakses tanggal 31 Agustus 2019.

${ }^{3}$ Sertifikasi green building diberikan oleh lembaga profesional untuk bangunan dengan desain eksterior dan interior (berikut rencana penggunaan energi) yang ramah lingkungan. Saat ini terdapat wacana untuk memberikan insentif khusus pada pemilik bangunan bersertifikat green building. Pamudji/FER, "Konsep Bangunan Hijau Butuh Insentif Pemerintah," https://www.beritasatu.com/ interior/154113-konsep-bangunan-hijau-butuh-insentif-pemerintah.html, diakses tanggal 31 Agustus 2019.

${ }^{4}$ Rencana Umum Ketenagalistrikan Nasional menyatakan bahwa tenaga surya merupakan sumber energi dengan potensi kedua terbesar di Indonesia (diprediksi bisa menghasilkan 207.898MW), di bawah penggunaan arus laut (dengan potensi teoretis sebesar 287.822MW). Indonesia, Menteri Energi dan Sumber Daya Mineral, Rencana Umum Ketenagalistrikan Nasional Tahun 2019 Sampai Dengan 2038, Keputusan No. 143 K/20/MEM/2019 Tahun 2019 (RUKN), Lampiran I, hlm. 228.

${ }^{5}$ Septian Denny, "Potensi Energi Tenaga Surya RI 10 Kali Lebih Besar dari Jerman," https:// www.liputan6.com/bisnis/read/2493191/potensi-energi-tenaga-surya-ri-10-kali-lebih-besar-dari- 
PLN vs Energi Terbarukan: Peraturan Menteri ESDM Terkait Penggunaan Sistem Pembangkit Listrik Tenaga Surya Atap

menjadikan pemasangan panel surya atap berikut perawatannya lebih mudah dan potensi akses masyarakat pada teknologi PLTS Atap relatif tinggi karena instalasi panel surya tidak memerlukan investasi tambahan untuk peletakannya.

\section{Kebijakan Energi Indonesia}

\section{A. Instrumen Internasional dan Undang-undang Ketenagalistri- kan}

Pada tataran internasional, Indonesia telah menunjukkan sikap proaktif dalam menentukan langkah-langkah penanggulangan dampak pemanasan global. Paris Agreement ${ }^{6}$ sebagai instrumen hukum internasional terbaru dalam bidang lingkungan yang diadopsi oleh Indonesia $^{7}$ menentukan panduan kuantitatif bagi tiap negara anggota dalam hal pengurangan jumlah emisi, dengan jalan konversi dari energi berbasis fosil dan langkah lainnya, demi tercapainya target pengurangan pemanasan global ke tingkat yang aman.

Undang-undang Ketenagalistrikan menetapkan keutamaan penggunaan energi baru dan terbarukan. ${ }^{8}$ Namun, amanat undang-undang ini belum dilaksanakan dengan maksimal, mengingat: (1) kenyataan Rencana Umum Energi Nasional (RUEN) dan dokumen turunannya yang masih menganggarkan penggunaan energi terbarukan dalam porsi bauran kurang dari $25 \%$ pada 2025, serta (2) kenyataan realisasi proyek-proyek pembangunan pembangkit listrik bertenaga terbarukan yang masih di bawah $10 \%$ dari jumlah seluruh pembangkit listrik untuk kepentingan umum. Dari sini terlihat bahwa Pemerintah belum memprioritaskan penggunaan energi terbarukan.

Sebagai ilustrasi, kapasitas terencana PLTS dengan baterai dalam Rencana Umum Ketenagalistrikan Nasional (RUKN) hanya ditargetkan sebesar 200

jerman?utm_expid=.9Z4i5ypGQeGiS7w9arwTvQ.0\&utm_referrer=https\%3A\%2F\%2Fwww.liputan6. com\%2Fbisnis\%2Fread\%2F2493191\%2Fpotensi-energi-tenaga-surya-ri-10-kali-lebih-besar-dari-jerman, diakses tanggal 14 Agustus 2019.

${ }^{6}$ Paris Climate Change Accord (Kesepakatan Paris) 2015 yang diadopsi oleh 195 negara pada 6th Annual Sustainable Innovation Forum (SIF15) di Paris, Perancis. Indonesia menandatangani Kesepakatan Paris pada 22 April 2016, dan meratifikasinya melalui Undang-Undang Nomor 16 Tahun 2016.

${ }^{7}$ Berbagai instrumen internasional lain yang telah ditandatangani Indonesia termasuk Copenhagen Accord (Kesepakatan Kopenhagen) 2009 yang meskipun tidak mengikat secara hukum memiliki arti penting bagi perkembangan kerja sama internasional dalam pengurangan emisi, dan Kyoto Protocol to the United Nations Framework Convention on Climate Change (Protokol Kyoto) yang diratifikasi melalui Undang-Undang Nomor 17 Tahun 2004 tentang Rencana Aksi Nasional Penurunan Emisi Gas Rumah Kaca yang dinilai tidak berhasil karena kurangnya mekanisme akuntabilitas bagi negara anggota pelanggar komitmen sukarela.

${ }^{8}$ Indonesia, Undang-Undang Ketenagalistrikan, UU No. 32 Tahun 2009, LN No. 133 Tahun 2009. TLN No. 5052, Pasal 6: "(2) Pemanfaatan sumber energi primer sebagaimana dimaksud pada ayat (1) harus dilaksanakan dengan mengutamakan sumber energi baru dan energi terbarukan." (Penekanan frasa oleh Penulis.) 
MW (dari kebutuhan total sebesar 127 GW) pada 2025. ${ }^{9}$ Dengan demikian dapat dipahami bahwa target PLN untuk meningkatkan bauran energi dari PLTS di dalam Rencana Usaha Penyediaan Tenaga Listrik (RUPTL) sebesar 3.200 MW pada 2025-2028 utamanya mengandalkan konsumen yang memasang panel surya dan bukan dari rencana nasional untuk pengembangan PLTS komersial. ${ }^{10}$ Hal ini sangat disayangkan, mengingat data Kementerian ESDM mengindikasikan potensi penggunaan energi baru dan terbarukan sebesar 442 Gigawatt Peak (GWp), dengan harapan PLTS dapat berkontribusi sebesar 207,8 GWp sedangkan realisasi pemanfaatan baru sebesar 0,092 GWp. ${ }^{11}$ Rasio itu menunjukkan ketertinggalan pemanfaatan potensi PLTS, bahkan ketika dibandingkan dengan negara-negara lain di Asia Tenggara dengan industri energi yang tidak semaju Indonesia: ${ }^{12}$

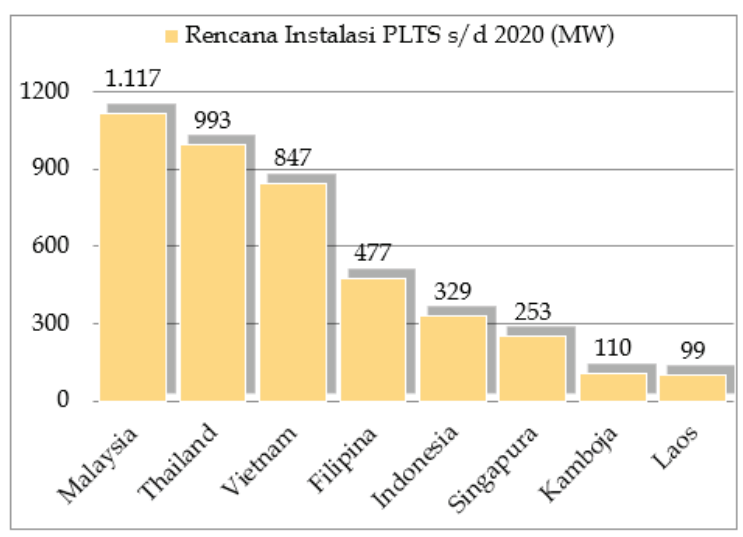

\section{Gambar 2. Rencana Instalasi PLTS s/d $2020(\mathrm{MW})^{13}$}

\section{B. Dokumen Perencanaan}

Komitmen internasional dan amanat undang-undang yang diejawantahkan dalam kebijakan energi Indonesia tertuang di berbagai dokumen perencanaan pembangunan bidang energi dari yang bersifat pedoman seperti Kebijakan Energi Nasional (KEN), RUEN, RUKN dan Rencana Umum Ketenagalistrikan Daerah (RUKD) hingga bersifat praktis dan dijadikan panduan bagi kalangan pelaku

\footnotetext{
${ }^{9}$ Indonesia, Menteri Energi dan Sumber Daya Mineral, Rencana Umum Ketenagalistrikan Nasional Tahun 2019 Sampai Dengan 2038, Keputusan No. 143 K/20/MEM/2019, hlm. 119.

${ }^{10}$ Indonesia, Menteri Energi dan Sumber Daya Mineral, Pengesahan Rencana Usaha Penyediaan Tenaga Listrik PT Perusahaan Listrik Negara (Persero) Tahun 2019 Sampai Dengan 2028, Keputusan No. 39 K/20/MEM/2019, hlm. V-64. PLTS yang direncanakan dalam RUPTL PLN sejatinya tidak termasuk fasilitas swadaya yang dibangun oleh masyarakat atau pelaku usaha untuk memenuhi kepentingannya sendiri. Rujuk penjelasan mengenai perbedaan pembangkit listrik untuk kepentingan umum dan untuk kepentingan sendiri pada bagian II.C.Pembangkit Listrik Tenaga Surya dalam Kerangka Kebijakan Energi.

${ }^{11}$ IDZ/BIR, "Energi Terbarukan Bisa Bikin Pemerintah Hemat Puluhan Triliun," https://www. cnnindonesia.com/ekonomi/20190424095301-85-389098/energi-terbarukan-bisa-bikin-pemerintahhemat-puluhan-triliun, diakses tanggal 14 Agustus 2019.

${ }^{12}$ Jason Thomas, "Indonesian Dull Solar Sector," https://theaseanpost.com/article/indonesiasdull-solar-sector, diakses tanggal 14 Agustus 2019.

${ }^{13}$ Stefan Robertsson, "Southeast Asian Solar: Market Outlook and Policy Overview," The Lantau Group, 31 Agustus 2017, https:// www.lantaugroup.com/files/ppt_pgen17_sr.pdf., diakses tanggal 15 Agustus 2019.
} 
PLN vs Energi Terbarukan: Peraturan Menteri ESDM Terkait Penggunaan Sistem Pembangkit Listrik

usaha: RUPTL. Tatanan kebijakan yang sedemikian sistematis sepatutnya mencerminkan keseriusan pemerintah dalam memenuhi komitmen internasionalnya dalam berbagai instrumen lingkungan yang telah diratifikasi dan menjadi bagian hukum Indonesia. Pada kenyataannya, kualitas hidup penduduk Indonesia terdampak negatif dengan pola pembangunan yang tidak berwawasan lingkungan seperti penyakit yang ditimbulkan akibat tingkat polusi yang semakin tinggi, baik di perkotaan maupun pelosok yang terpapar emisi industri. ${ }^{14}$ Belum lagi hilangnya habitat alami yang mengancam kepunahan berbagai flora dan fauna. Dampak lingkungan semestinya menjadi komponen pertimbangan penting dalam perencanaan pembangunan energi di Indonesia. Namun, itikad baik dan kebijakan umum belum tercermin dalam dokumen-dokumen perencanaan tersebut.

Gambar di bawah memperlihatkan ketimpangan antara rencana pembangunan pembangkit energi terbarukan berdasarkan komitmen yang diutarakan Pemerintah dalam RUEN dan kenyataan RUPTL saat ini: 15

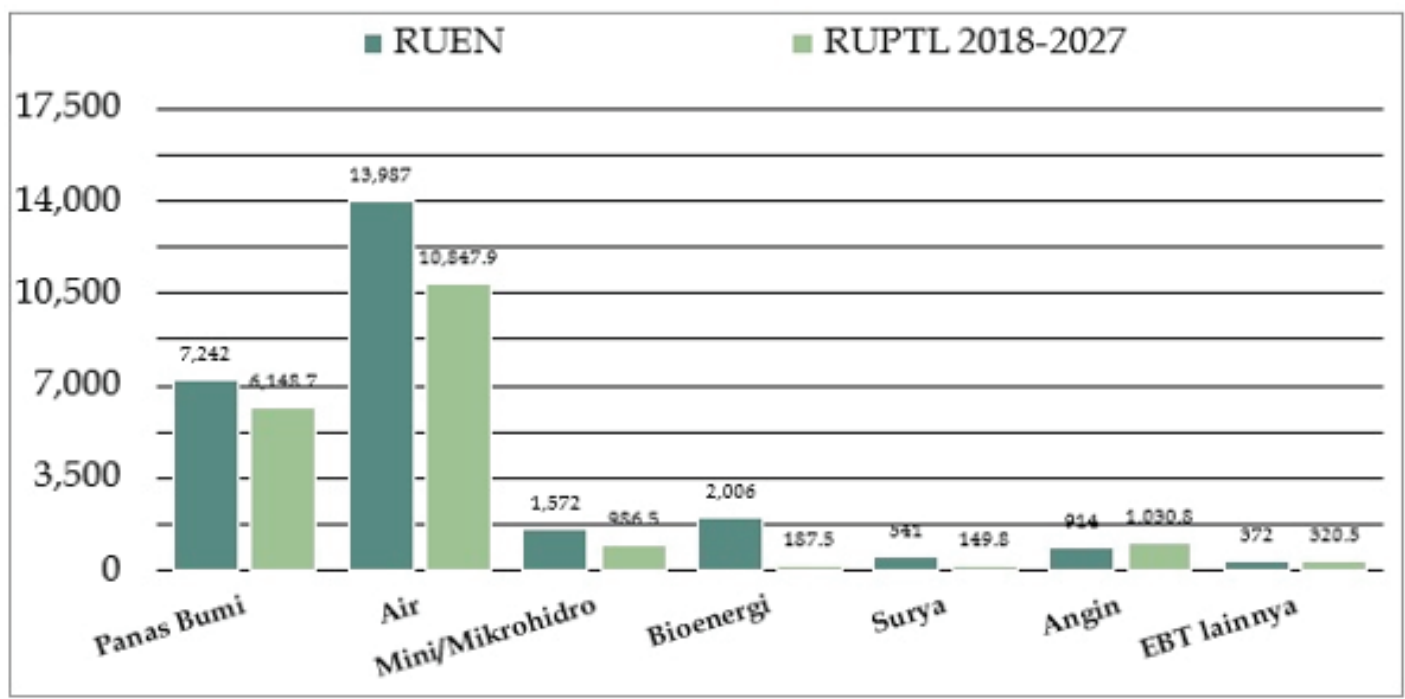

Gambar 3. Perbandingan Rencana Instalasi EBT (MW) ${ }^{16}$

\footnotetext{
${ }^{14}$ Lalu Rahadian, "Ini 10 PLTU yang Berpotensi Sumbang Polusi Udara Jakarta," https:/ jakarta. bisnis.com/read/20190716/77/1124981/ini-10-pltu-yang-berpotensi-sumbang-polusi-udara-jakarta, diakses tanggal 17 Agustus 2019. Mengutip Dwi Saung, peneliti lingkungan hidup dari Wahana Lingkungan Hidup Indonesia (Walhi), artikel menyebut PLTU dan industri berbahan bakar batubara menyumbang setidaknya 20-30\% polusi udara di DKI Jakarta.

${ }^{15}$ Grita Anindarini Widyaningsih, “Membedah Kebijakan Perencanaan Ketenagalistrikan di Indonesia," Jurnal Hukum Lingkungan Indonesia, Vol. 5 No. 1 (2018), hlm. 117-136, https:/ /icel.or.id/wp-content/uploads/JHLI-5.1-FINAL-compressed.pdf.

${ }^{16} \mathrm{Ibid}$. Penulis mengolah data yang disampaikan dalam bentuk tabel pada halaman 131-132 dari artikel tersebut menjadi gambar.
} 
Selisih tersebut tidaklah mengherankan mengingat:

1. KEN secara eksplisit masih menyebut keutamaan penggunaan batubara untuk memenuhi target rasio elektrifikasi; ${ }^{17}$

2. Tidak terdapat mekanisme yang jelas untuk memastikan bahwa kebijakan pelaksana yang tingkatnya lebih rendah dari KEN tunduk terhadap instrumen hukum induknya, khususnya dalam menentukan jumlah tenaga yang direncanakan untuk tiap koridor; ${ }^{18}$

3. Melebihi pertimbangan lain kelestarian lingkungan hidup, RUPTL disusun sebagai strategi usaha PLN yang berpedoman pada perolehan manfaat ekonomi; ${ }^{19}$ dan
4. Visi PLN tidak memperhitungkan potensi $\mathrm{EBT}^{20}$

\section{Pembangkit Listrik Tenaga Sur- ya dalam Kerangka Kebijakan Energi}

Seperti halnya pembangkit dengan sumber tenaga lain, RUPTL hanya mengatur PLTS yang dibangun untuk kepentingan umum. PLTS yang dimaksud adalah proyek berskala besar yang dibangun sebagai industri penjualan tenaga listrik kepada transmisi PLN untuk kemudian didistribusikan kepada pelanggan umum. PLTS Atap tidak termasuk dalam kapasitas yang direncanakan dalam RUPTL karena sifatnya yang swasembada dan mengikuti kebutuhan dan kemampuan si pemilik.

\section{${ }^{17}$ Ibid., hlm. 122.}

${ }^{18}$ Ibid., hlm. 133. RUEN mengidentifikasi potensi suplai tenaga listrik dari PLTS sebesar 207GW atau sekitar 1035 kali dari rencana yang dituangkan dalam RUKN.

${ }^{19}$ Indonesia, Op. Cit., RUPTL PLN 2019-2028, hlm. II-2 - II.11, 2.2. Strategi Pengembangan Kapasitas Pembangkit, PLN secara gamblang menyebut prinsip pengadaan adalah dengan biaya penyediaan listrik terendah (least cost). Pembangkit EBT “..'didorong' namun dengan tetap mempertimbangkan keekonomian (efisiensi harga)..". Khususnya untuk PLTS, PLN mengutip kebijakan ESDM pada Peraturan Menteri ESDM Nomor 50 Tahun 2017 tentang Pemanfaatan Sumber Energi Terbarukan untuk Penyediaan Tenaga Listrik yang menetapkan pagu 85\% dari Biaya Pokok Penyediaan Pembangkitan (BPP) setempat oleh pembangkit PLN untuk tarif pembelian listrik dari PLTSA. Secara efektif, ESDM memastikan PLTSA tidak dapat bersaing secara ekonomis dengan PLN. Hal ini konsisten dengan kebijakan RUPTL yang menekankan penghindaran kenaikan BPP akibat harga listrik dari energi terbarukan (hlm. III.15) yang dikhawatirkan dapat menyebabkan penurunan demand listrik pelanggan PLN (hlm. II-1).

${ }^{20}$ Ibid., hlm. II-30 - II-31, 2.7. Strategi Penurunan Emisi Gas Rumah Kaca (GRK). Meskipun PLN menyatakan dirinya sebagai 'bagian dari' komitmen Pemerintah dalam Paris Agreement, tidak terlihat upaya nyata dari PLN untuk melakukan pengurangan GRK secara signifikan mengingat (a) strategi PLN masih mengandalkan teknologi PLTU Batubara yang 'ramah lingkungan', dan (b) pengutamaan pengembangan EBT pada bagian perencanaan dalam RUPTL yang bersangkutan (misal: RUPTL hlm. III-14, Tabel 3.2 Rencana Pengembangan Pembangkit EBT (MW), yang menempatkan target pembangunan pembangkit EBT pada laju yang sangat rendah dibandingkan dengan potensinya seperti ditunjukkan pada Tabel 3.1 Potensi Energi Baru dan Terbarukan.) Untuk ulasan lebih jauh mengenai disparitas perencanaan pembangkit EBT vs fosil lihat: Grita, Op. Cit., hlm. 129-133. 
PLN vs Energi Terbarukan: Peraturan Menteri ESDM Terkait Penggunaan Sistem Pembangkit Listrik Tenaga Surya Atap

Pembangkit listrik untuk kepentingan sendiri lazim ditemukan pada perusahaan pertambangan atau manufaktur yang membutuhkan energi listrik yang besar. Alasan keekonomian atau lokasi pertambangan yang terpencil, belum tersedianya listrik dari PLN, terkadang memberikan inisiatif kepada perusahaan-perusahaan tersebut untuk membangun sendiri pembangkit listriknya dan memasang sendiri instalasi penyaluran tenaga sesuai rancangan fasilitas yang bersangkutan. Pemerintah (ESDM), gubernur atau bupati memberi izin sebelum pembangunan pembangkit yang bersangkutan dapat dilakukan ${ }^{21}$ berdasarkan kelengkapan persyaratan seperti kelaikan desain dan studi dampak lingkungan. Seringkali pembangkit listrik untuk kepentingan sendiri menghasilkan tenaga listrik yang melebihi kapasitas yang dibutuhkan untuk menjalankan operasional industri yang bersangkutan (excess power). Demi menyokong rasio elektrifikasi terhadap masyarakat luas, Pemerintah memperbolehkan produsen captive power untuk menjual kelebihan te- naga tersebut dan dimanfaatkan bagi kepentingan umum dengan persetujuan sebelumnya dari Kementerian ESDM atau kepala daerah. ${ }^{22}$ Dalam hal pembangkit menggunakan energi terbarukan, ESDM mengharuskan PLN untuk membeli kelebihan tenaga tersebut dengan memperhatikan kebijakan energi nasional dan rencana umum ketenagalistrikan. ${ }^{23}$

\section{Peraturan Menteri Energi dan Sumber Daya Mineral terkait Penggunaan Sistem Pembang- kit Listrik Tenaga Surya Atap oleh Konsumen PT PLN}

\section{A. Kebijakan Baru yang Membe- ratkan}

Peraturan ESDM No. 49 Tahun 2018, sebagaimana diubah dalam Peraturan ESDM No. 13 Tahun 2019 (Permen ESDM terkait Penggunaan Sistem PLTS Atap oleh Konsumen PT PLN) diterbitkan sebagai implementasi mandat Pemerintah bagi PLN untuk membeli excess power dari PLTS Atap milik pelanggan PLN. Dalam bagian pertimbangan dari

${ }^{21}$ Kewenangan Bupati dalam memberikan izin pembangunan berdasarkan Undang-Undang Ketenagalistrikan secara implisit dicabut dengan Indonesia, Undang-Undang Pemerintahan Daerah, UU No. 23 Tahun 2014, LN No. 244 Tahun 2014, TLN No. 5587 tidak lagi menempatkan kewenangan tersebut pada level Kabupaten. Rujuk penjelasan pada catatan kaki 33 dan 38 mengenai kewenangan Bupati dalam memberi izin pembangkit listrik pasca diundangkannya Undang-Undang Pemerintahan Daerah.

${ }^{22}$ Indonesia, Op. Cit., Undang-Undang Ketenagalistrikan, Ps. 23 (3).

Indonesia, Menteri Energi dan Sumber Daya Mineral, Pemanfaatan Sumber Energi Terbarukan Untuk Penyediaan Tenaga Listrik, Peraturan No. 50 Tahun 2017, BN No. 1107 Tahun 2017, Pasal. 2.

${ }^{23}$ Indonesia, Menteri Energi dan Sumber Daya Mineral, Penggunaan Sistem Pembangkit Listrik Tenaga Surya Atap oleh Konsumen PT Perusahaan Listrik Negara (Persero), Peraturan No. 49 Tahun 2018 (Peraturan ESDM No. 49 Tahun 2018, sebagaimana diubah dalam Peraturan Menteri ESDM No. 13 Tahun 2019), BN No. 1525 Tahun 2018, Pertimbangan (a). 
peraturan yang bersangkutan, ${ }^{24}$ dan paparan $\mathrm{ESDM}^{25}$ tujuan instalasi PLTS Atap adalah untuk penghematan biaya rekening pelanggan PLN. Pemerintah menentukan sejumlah norma baru bagi instalasi dan pembelian excess power dari PLTS Atap:

1. Kewajiban memperoleh izin instalasi dari PLN;

2. Kapasitas maksimal ditentukan sebesar 100\% dari daya tersambung PLN;

3. Besaran excess power yang dibeli oleh PLN dari PLTS Atap adalah $65 \%$ dari nilai nyata kelebihan tenaga yang tercatat pada meteran PLN; dan

4. Kewajiban bagi pelanggan PLN kategori industri yang hendak menggunakan PLTS Atap untuk membayar biaya kapasitas (capacity charge).

Ditinjau dari kebijakan yang berlaku terhadap PLTS Atap sebelum peraturan ini berlaku, tampaknya Pemerintah me- lupakan amanat undang-undang Ketenagalistrikan untuk memberi pengutamaan terhadap sumber energi baru dan terbarukan. Diskriminasi terhadap perlakuan pembelian excess power dari PLTS Atap dibanding dengan pembangkit lain termasuk yang berbahan bakar fosil terlihat secara gamblang dari pembatasan kapasitas terpasang dan besaran pembelian, serta pengenaan biaya tambahan. Keseluruhan ketentuan tersebut baru diperkenalkan dalam Permen ESDM terkait Penggunaan Sistem PLTS Atap oleh Konsumen PT PLN. Sebelumnya, pelanggan on-grid hanya cukup mendapatkan sertifikat laik operasi dari PLN sebelum pengoperasian. Dengan berbagai aturan baru ini, pelanggan PLN yang hendak memasang PLTS Atap menjadi sangat dirugikan. Asosiasi pelanggan dan produsen komersial telah menyatakan keberatannya terhadap aturan-aturan tersebut, dan beberapa PLTS Atap rumahan memutuskan untuk tidak lagi menjadi

\footnotetext{
${ }^{24}$ Peraturan Menteri ESDM ini telah diubah melalui: (i) Indonesia, Peraturan Menteri Energi dan Sumber Daya Mineral, Perubahan atas Peraturan Menteri Energi dan Sumber Daya Mineral Nomor 49 Tahun 2018 tentang Penggunaan Sistem Pembangkit Listrik Tenaga Surya Atap oleh Konsumen PT Perusahaan Listrik Negara (Persero), Peraturan No. 13 Tahun 2019, BN No. 1020 Tahun 2019, yang mengubah batas kapasitas produksi listrik yang wajib memperoleh sertifikat laik operasi mengikuti ketentuan Peraturan ESDM lainnya (Peraturan Menteri Energi dan Sumber Daya Mineral No. 12 Tahun 2019 tentang Kapasitas Pembangkit Tenaga Listrik untuk Kepentingan Sendiri yang Dilaksanakan berdasarkan Izin Operasi); dan (ii) Indonesia, Peraturan Menteri Energi dan Sumber Daya Mineral, Perubahan Kedua atas Peraturan Menteri Energi dan Sumber Daya Mineral Nomor 49 Tahun 2018 tentang Penggunaan Sistem Pembangkit Listrik Tenaga Surya Atap oleh Konsumen PT Perusahaan Listrik Negara (Persero), Peraturan No. 16 Tahun 2019, BN No. 1179 Tahun 2019, yang mengganti besaran pengali biaya kapasitas (capacity charge) dan meniadakan pengenaan biaya pembelian energi listrik darurat (emergency charge) bagi konsumen PLN kelas industri.

${ }^{25}$ Tim Komunikasi ESDM, “Narasi Tunggal: Pasang PLTS Atap, Tagihan Listrik Lebih Hemat," https:// www.esdm.go.id/id/media-center/arsip-berita/narasi-tunggal-pasang-plts-atap-tagihan-listrik-lebih-hemat, diakses tanggal 31 Agustus 2019.
} 
PLN vs Energi Terbarukan: Peraturan Menteri ESDM Terkait Penggunaan Sistem Pembangkit Listrik

pelanggan PLN (off-grid) dengan membeli baterai penyimpan kelebihan tenaga untuk memenuhi kebutuhan intermittent listriknya. Biaya instalasi PLTS Atap dengan baterai dilaporkan mencapai 50\% lebih mahal dari biaya instalasi normal. ${ }^{26}$ Perizinan administratif yang harus diajukan sebelum instalasi dengan melibatkan sejumlah institusi ketenagalistrikan terdaftar memberatkan pelanggan dan berpotensi meningkatkan lagi harga instalasi. Dengan disinsentif demikian, makin sedikit jumlah konsumen yang mampu beralih ke PLTS Atap.

\section{B. Permasalahan Hukum dalam Peraturan Menteri ESDM terkait Penggunaan Sistem PLTS Atap oleh Konsumen PT PLN}

\section{Kedudukan dan Fungsi PLN se- bagai Pemberi Izin}

Pertanyaan pertama yang timbul dari Permen ESDM tersebut adalah me- ngenai kedudukan PLN ditinjau dari kewenangan pemberian izin pembangunan PLTS Atap yang diwajibkan Pasal 10 ayat (1). Monopoli Negara terhadap bidang usaha yang menguasai hajat hidup orang banyak sesuai dengan Pasal 33 Undang-undang Dasar (UUD) tidak dapat diterjemahkan untuk dinikmati secara otomatis oleh PLN. Dalam bidang penyediaan tenaga listrik, Undang-undang Ketenagalistrikan memastikan kedudukan usaha penyediaan tenaga listrik sebagai salah satu cabang usaha sebagaimana dimaksud Pasal 33 UUD, dan menekankan kewenangan penyelenggaraan Pemerintah untuk usaha penyediaan tersebut. $^{27}$

Kewenangan penyelenggaraan penyediaan tenaga listrik Pemerintah secara garis besar melingkupi kewenangan penetapan kebijakan, pengaturan, pengawasan, dan melaksanakan usaha penyediaan tenaga listrik. ${ }^{28}$ Kewenangan penetapan kebijakan, pengaturan dan

\footnotetext{
${ }^{26}$ Stefanno Reinard Sulaiman, "New solar panel regulation discourages public use," https://www. thejakartapost.com/news/2019/02/22/new-solar-panel-regulation-discourages-public-use.html, diakses tanggal 16 Agustus 2019.

${ }^{27}$ Indonesia, Undang-Undang Dasar Negara Republik Indonesia, Pasal 33 mengenai Kesejahteraan Sosial menyatakan bahwa: (1) Perekonomian disusun sebagai usaha bersama berdasar atas asas kekeluargaan. (2) Cabang-cabang produksi yang penting bagi negara dan yang menguasai hajat hidup orang banyak dikuasai oleh negara. (3) Bumi dan air dan kekayaan alam yang terkandung didalamnya dikuasai oleh negara dan dipergunakan untuk sebesar-besarnya kemakmuran rakyat.

Indonesia, Op. Cit., Undang-Undang Ketenagalistrikan, Penjelasan Umum Paragraf 2: "Mengingat arti penting tenaga listrik bagi negara dalam mewujudkan kesejahteraan masyarakat dalam segala bidang dan sejalan dengan ketentuan dalam Pasal 33 ayat (2) Undang-Undang Dasar Negara Republik Indonesia Tahun 1945, Undang-Undang ini menyatakan bahwa usaha penyediaan tenaga listrik dikuasai oleh negara dan dipergunakan untuk sebesar-besar kemakmuran rakyat yang penyelenggaraannya dilakukan oleh Pemerintah dan pemerintah daerah."

${ }^{28}$ Ibid, Pasal. 3(2).
} 
pengawasan penyediaan ketenagalistrikan tetap dipegang oleh Pemerintah dan pemerintah daerah yang pada praktiknya meliputi:

a. penetapan izin usaha penyediaan tenaga listrik (bagi pemilik pembangkit untuk kepentingan umum);

b. penetapan izin operasi (bagi pemilik pembangkit untuk kepentingan sendiri); dan

c. penetapan persetujuan penjualan kelebihan tenaga listrik dari pemegang izin operasi. ${ }^{29}$

Sedangkan, pelimpahan kewenangan kepada PLN (atau BUMD yang dapat ditunjuk Pemerintah Daerah) hanyalah pada bidang pelaksanaan usaha tenaga listrik. ${ }^{30}$ Sesuai dengan Pasal 10 ayat (1) Undang-undang Ketenagalistrikan, lingkup usaha PLN sebagai BUMN yang ditunjuk oleh Pemerintah sebagai penyelenggara penyediaan tenaga listrik untuk kepentingan umum hanyalah meliputi:

a. pembangkitan tenaga listrik;

b. transmisi tenaga listrik;

c. distribusi tenaga listrik; dan/ atau

d. penjualan tenaga listrik.

Dengan demikian, dapat terlihat dalam Undang-undang Ketenagalistrikan bahwa penugasan PLN tidak termasuk pemberian perizinan sebagaimana diatur oleh Permen ESDM terkait Penggunaan Sistem PLTS Atap oleh Konsumen PT PLN Sebaliknya, Undang-undang Ketenagalistrikan tidak mengizinkan Pemerintah untuk memberikan kewenangan tersebut kepada PLN karena batasan lingkup kewenangan PLN pada Pasal 4 ayat (1) hanya meliputi "pelaksanaan kegiatan usaha" dan sifat kegiatannya sangat spesifik untuk pengusahaan seperti yang telah dijabarkan Pasal 10 tersebut. Wewenang lain Pemerintah berupa "penetapan kebijakan", "pengaturan", dan "pengawasan" tidak turut didelegasikan dalam undang-undang Ketenagalistrikan. Konsekuensinya, Pemerintah tidak berwenang untuk menugaskan PLN melaksanakan fungsi-fungsi tersebut meskipun penugasan dilakukan melalui Permen ESDM tersebut. Secara teori peraturan perundang-undangan, Permen ESDM tersebut melanggar dasar hukum penerbitannya karena penugasan tersebut tidak diizinkan UUD dan Undangundang Ketenagalistrikan yang secara tegas membatasi lingkup fungsi badan usaha sebagai pelaksana penyediaan tenaga listrik. ${ }^{31}$

\footnotetext{
${ }^{29}$ Ibid, Pasal. 5.

${ }^{30}$ Ibid, Pasal. 4(1): "Pelaksanaan usaha penyediaan tenaga listrik oleh Pemerintah dan pemerintah daerah dilakukan oleh badan usaha milik negara dan badan usaha milik daerah."

${ }^{31}$ Zaka Firma Aditya dan M. Reza Winata, "Rekonstruksi Hierarki Peraturan Perundang-undangan di Indonesia", Negara Hukum: Membangun Hukum untuk Keadilan dan Kesejahteraan, Vol. 9, No. 1 (2018),
} 
PLN vs Energi Terbarukan: Peraturan Menteri ESDM Terkait Penggunaan Sistem Pembangkit Listrik Tenaga Surya Atap

\section{Pengenalan Rezim Perizinan Baru tanpa Dasar Hukum}

Ditinjau dari sifat perizinan yang disyaratkan Permen ESDM sebagaimana disebut di atas, ESDM juga tampak telah menciptakan kategori perizinan baru yang tidak didasarkan pada Undangundang Ketenagalistrikan. Peraturan Menteri tidak diperkenankan untuk bertentangan dengan peraturan landasannya. Bahkan, UU Nomor 12 Tahun 2011 tentang Pembentukan Peraturan Perundang-undangan menjelaskan bahwa kekuatan mengikat dari peraturan menteri hanya sepanjang diperintahkan oleh Peraturan Perundang-undangan yang lebih tinggi atau dibentuk berdasarkan kewenangan. ${ }^{32}$

Dalam Undang-undang Ketenagalistrikan dan PP Nomor 14 Tahun 2012 tentang Kegiatan Usaha Penyediaan Tenaga
Listrik, hanya dikenal dua macam izin pembangunan fasilitas pembangkit listrik, yaitu Izin Usaha Penyediaan Tenaga Listrik (IUPTL) yang ditujukan bagi pembangkit listrik untuk kepentingan umum, dan Izin Operasi (IO) untuk pembangkit listrik untuk kepentingan sendiri dengan kapasitas tertentu. Kedua izin tersebut disyaratkan sebelum pembangunan pembangkit dapat dilakukan, hingga sifatnya mirip dengan izin PLTS Atap yang disyaratkan Pasal 10 ayat (1) Permen ESDM terkait Penggunaan Sistem PLTS Atap oleh Konsumen PT PLN.

Ketentuan umum yang berlaku terhadap segala jenis pembangkit listrik untuk kepentingan sendiri dengan kapasitas sampai dengan $500 \mathrm{kVA}^{33}$ adalah bahwa pemilik tidak perlu mendapatkan IO ataupun SLO, dan hanya perlu menyampaikan laporan kepada Kementeri-

hlm. 81. Mengutip Retno Saraswati dalam “Perkembangan Pengaturan Sumber Hukum dan Tata Urutan Perundang-undangan di Indonesia", Media Hukum, Vol. IX, No. 2, April-Juni 2009, hlm. 1, antara lain menyebut bahwa tata urutan atau hierarki peraturan perundang-undangan memiliki makna bahwa: “(a) Peraturan hukum atasan merupakan dasar hukum pembentukan peraturan hukum bawahan, (b) Peraturan hukum bawahan merupakan pelaksanaan peraturan hukum atasan, oleh karena itu kedudukannya lebih rendah dan materi muatannya tidak boleh bertentangan."

32 Indonesia, Undang-Undang Pembentukan Peraturan Perundang-undangan, UU No. 12 Tahun 2011, LN No. 82 Tahun 2011, TLN No. 5234, sebagaimana diubah dengan Indonesia, Undang-Undang tentang Perubahan atas Undang-Undang Nomor 12 Tahun 2011 tentang Pembentukan Peraturan Perundang-undangan, UU No. 15 Tahun 2019, LN No. 183 Tahun 2019, TLN No. 6398, Pasal 8(2). Selanjutnya, menurut Penjelasan Pasal 8(2):

"Yang dimaksud 'berdasarkan kewenangan' berarti penyelenggaraan urusan tertentu pemerintahan sesuai dengan ketentuan Peraturan Perundang-undangan."

Sekali lagi, peraturan menteri tidak dibenarkan untuk melakukan fungsi pengaturan (beleid) tanpa adanya dasar pemberian kewenangan untuk melakukan hal tersebut seperti mandat Undang-Undang. Lihat: Zaka Firma Aditya dan M. Reza Winata, Op. Cit., hlm. 95.

${ }^{33}$ Kapasitas pembangkit untuk kepentingan sendiri yang wajib memperoleh IO dan SLO baru saja dinaikkan dengan Peraturan ESDM No. 13 Tahun 2019, sedangkan sebelumnya pembangkit untuk kepentingan sendiri yang berkapasitas $>200 \mathrm{kVA}$ wajib memperoleh IO dan SLO. 
an ESDM cq. Direktur Jenderal Ketenagalistrikan atau Gubernur. Sedangkan untuk pembangkit dengan kapasitas >500 kVA pemilik diwajibkan memperoleh IO, baik dari Kementerian ESDM atau Pemerintah Daerah. ${ }^{34}$

IO diberikan kepada pembangkit untuk kepentingan sendiri dengan persyaratan yang lebih rendah dari IUPTL untuk kepentingan umum. Di samping persyaratan dasar yang berlaku untuk IO maupun IUPTL seperti data administratif, kajian teknis dan lingkungan, IUPTL untuk pembangkit listrik yang diberikan kepada pembangkit milik swasta (IPP) mensyaratkan adanya studi kelayakan usaha untuk IPP yang bersangkutan, perjanjian pembelian tenaga listrik ( $p o-$ wer purchase agreement - PPA) yang telah ditandatangani antara IPP dengan pembeli tenaga listrik (off-taker - dapat berupa PLN atau perusahaan lain yang memerlukan suplai eksklusif dari pembangkit), dan terlebih lagi diperlukan adanya sinergi antara pembangkit dengan RUPTL sehingga diperlukan kajian khusus untuk menentukan kapasitas penyediaan oleh PLN dan rencana penyambungan kepada jaringan distribusi PLN. ${ }^{35}$
Di samping IUPTL dan IO, “izin" yang berlaku umum terhadap seluruh instalasi ketenagalistrikan (termasuk jaringan transmisi, distribusi, dan instalasi listrik konsumen) adalah Sertifikat Laik Operasi (SLO) yang berlaku termasuk untuk PLTS Atap demi menjamin keamanan fasilitas yang bersangkutan. Sebelum pemberlakuan Permen ESDM tersebut, tidak dikenal konsep izin tersendiri yang harus diterbitkan sebelum perorangan maupun pelaku usaha dapat memasang PLTS Atap. SLO, yang masih diwajibkan dalam Peraturan tersebut, diterbitkan setelah instalasi rampung dan dapat diuji coba.

Patut digarisbawahi bahwa tidak satu pun dari IUPTL atau IO dapat diterbitkan oleh PLN. Kewenangan untuk menerbitkan izin tetap ada pada Pemerintah Pusat yang dalam hal ini adalah Kementerian ESDM ataupun Pemerintah Daerah, sedangkan kedudukan PLN dalam Undang-undang Ketenagalistrikan dan Peraturan Pemerintah tentang Penyediaan Tenaga Listrik sangat jelas hanya semata sebagai subjek pemegang IUPTL. SLO sendiri diberikan ESDM, gubernur atau bupati/walikota setelah dilakukan pemeriksaan dan pengujian

\footnotetext{
${ }^{34}$ Indonesia, Menteri Energi dan Sumber Daya Mineral, Kapasitas Pembangkit Tenaga Listrik Untuk Kepentingan Sendiri Yang Dilaksanakan Berdasarkan Izin Operasi, Peraturan No. 29 Tahun 2012, BN No. 1255 Tahun 2012, Pasal 2 (1).

${ }^{35}$ Indonesia, Kegiatan Usaha Penyediaan Tenaga Listrik, Peraturan Pemerintah No. 14 Tahun 2012, LN No. 28 Tahun 2012, TLN 5281, Bab II Bagian Kedua (Usaha Penyediaan Tenaga Listrik Untuk Kepentingan Umum) dan Bagian Ketiga (Usaha Penyediaan Tenaga Listrik Untuk Kepentingan Sendiri).
} 
PLN vs Energi Terbarukan: Peraturan Menteri ESDM Terkait Penggunaan Sistem Pembangkit Listrik Tenaga Surya Atap

oleh lembaga inspeksi teknis yang terakreditasi oleh ESDM. ${ }^{36}$

\section{Kewenangan ESDM dalam Pemberian Penugasan}

Permasalahan hukum pun muncul berkaitan dengan penugasan terhadap PLN dari ESDM untuk memberi izin PLTS Atap. Wewenang Pemerintah Pusat (ESDM) menurut Undang-undang Ketenagalistrikan yang dapat dilimpahkan kepada PLN terbatas pada fasilitas ketenagalistrikan tertentu saja. Seperti penjabaran Pasal 5 ayat (1) Undangundang Ketenagalistrikan, Pemerintah (ESDM) berwenang memberi IUPTL dan IO dalam hal:

a. Badan usaha merupakan BUMN atau wilayah usahanya lintas provinsi;

${ }^{36}$ Ibid., Pasal 46.

${ }^{37}$ Menjadi pertanyaan terpisah apakah pemberian izin dalam hal PLTS Atap dalam area kabupaten menjadi kewenangan Bupati karena adanya konflik antara Undang-Undang Ketenagalistrikan dengan Undang-Undang Pemerintah Daerah yang tidak lagi memberikan kewenangan pemberian izin pembangkit kepada Bupati (meskipun pembagian tersebut tidak spesifik diberlakukan terhadap PLTS Atap). Mahkamah Konstitusi dalam Putusan Nomor 11/PUU-XIV/2016 mengenai kewenangan pemberian izin pemanfaatan panas bumi (Pemerintah Provinsi Jawa Timur vs Pemerintah Republik Indonesia) memutuskan bahwa sifat energi panas bumi yang tidak bisa secara mudah didelineasi ke dalam batasan wilayah administratif membenarkan pemusatan kewenangan perizinan kepada Pemerintah RI berdasarkan Undang-Undang Pemerintah Daerah, meskipun Undang-Undang Panas Bumi No. 21 Tahun 2014 (sebagaimana Undang-Undang Ketenagalistrikan) memberikan kewenangan perizinan kepada Pemerintah Provinsi. Akan sulit membenarkan posisi tersebut (menarik kuasa perizinan dari pemerintah daerah ke Pemerintah Pusat dan, sebagai konsekuensi, membenarkan pemberian penugasan melalui Peraturan ESDM kepada PLN untuk memberikan izin dalam segala skenario pembangunan PLTS Atap) dalam kasus PLTS Atap karena (1) energi surya tidak mengenal batas ketersediaan dalam satu wilayah dan tidak memerlukan ekstraksi sehingga membutuhkan koordinasi khusus oleh Pemerintah Pusat seperti dalam kasus panas bumi, dan (2) Penarikan wewenang dalam skenario ini dilakukan hanya melalui level peraturan menteri karena Undang-Undang Ketenagalistrikan tidak mengenal perizinan untuk PLTS Atap (rujuk Bagian III.C.2. Pengenalan Rezim Perizinan Baru tanpa Dasar Hukum diatas).

${ }^{38} \mathrm{Hal}$ ini juga ditegaskan oleh Undang-Undang Ketenagalistrikan yang dalam Penjelasan Umum Paragraf 3 menjelaskan: "Sesuai dengan prinsip otonomi daerah, Pemerintah atau pemerintah daerah sesuai dengan kewenangannya menetapkan izin usaha penyediaan tenaga listrik." 
menjamin terselenggaranya pemerintahan daerah yang kebijakannya memenuhi kebutuhan masyarakat setempat dan menghormati kearifan lokal dan tidak semata-mata menjalankan kebijakan Pemerintah pusat.

Dengan demikian, sebagaimana dijamin oleh $U_{U D}^{38}$ serta asas pembentukan peraturan perundang-undangan yang baik $^{39}$, kepala pemerintahan daerah sendirilah yang berwenang untuk menugaskan badan usaha atau instansi lainnya untuk menjalankan fungsinya. Prinsip ini juga tertuang secara tegas dalam Undang-undang Ketenagalistrikan yang memisahkan kewenangan penyelenggaraan penyediaan tenaga listrik kepada tiap-tiap unit Pemerintahan Pusat, Provinsi, dan Kabupaten/Kota setara sesuai dengan luasan pengusahaan dan ketersambungan pembangkit dengan jaringan. Pelaksanaan fungi pemerintah- an melalui penugasan kepada instansi usaha milik pemerintah lazim dilakukan secara mandiri oleh Pemerintah Daerah melalui peraturan gubernur atau peraturan bupati seperti yang dilakukan oleh Gubernur DKI Jakarta kepada Perusahaan Daerah untuk penyelenggaraan fasilitas pengolahan sampah antara di dalam kota. ${ }^{40}$

Untuk merealisasikan kewenangan PLN dalam memberi izin PLTS Atap seperti diinginkan Pasal 10 ayat (1) Permen ESDM tersebut, seyogyanya (a) satu per satu Gubernur dan Bupati harus menerbitkan peraturan yang menunjuk PLN untuk melaksanakan kewenangan perizinan mereka berdasarkan Undangundang Ketenagalistrikan, atau (b) Undang-undang Ketenagalistrikan menciptakan kewenangan perizinan baru untuk pembangunan PLTS Atap dan menetapkan Pemerintah Pusat sebagai

${ }^{38}$ Undang-Undang Dasar Negara Republik Indonesia (sebagaimana diamandemen) Pasal 18 (5) mengatakan hanya undang-undang yang dapat menetapkan urusan pemerintahan sebagai urusan Pemerintah Pusat.

${ }^{39}$ Sebagaimana diatur dalam Pasal 5 Undang-Undang No. 12 Tahun 2011 yang dalam penjelasannya mensyaratkan peraturan perundang-undangan untuk dibentuk dengan memperhatikan asas kelembagaan atau pejabat pembentuk yang tepat dan asas kesesuaian antara jenis, hierarki, dan materi muatan:

"Hurufb

Yang dimaksud dengan "asas kelembagaan atau pejabat pembentuk yang tepat" adalah bahwa setiap jenis Peraturan Perundang-undangan harus dibuat oleh lembaga negara atau pejabat Pembentuk Peraturan Perundang-undangan yang berwenang. Peraturan Perundang-undangan tersebut dapat dibatalkan atau batal demi hukum apabila dibuat oleh lembaga negara atau pejabat yang tidak berwenang.

Hurufc

Yang dimaksud dengan "asas kesesuaian antara jenis, hierarki, dan materi muatan" adalah bahwa dalam Pembentukan Peraturan Perundang-undangan harus benar-benar memperhatikan materi muatan yang tepat sesuai dengan jenis dan hierarki Peraturan Perundang-undangan."

${ }^{40}$ Daerah Khusus Ibukota Jakarta, Penugasan kepada Perseroan Terbatas Jakarta Propertindo (Perusahaan Daerah) dalam Penyelenggaraan Fasilitas Pengolahan Sampah Antara di Dalam Kota, Peraturan Nomor 65 Tahun 2019, Berita Daerah Nomor 73004 Tahun 2019. 
PLN vs Energi Terbarukan: Peraturan Menteri ESDM Terkait Penggunaan Sistem Pembangkit Listrik Tenaga Surya Atap

pihak yang berwenang. Oleh karena itu, dengan memberi kewenangan umum kepada PLN untuk memberi izin instalasi PLTS Atap, ESDM melanggar lingkup kewenangannya dalam Undang-undang Ketenagalistrikan dan melanggar Undang-undang Dasar yang menjamin wewenang pemerintah daerah untuk melaksanakan fungsi pengaturan dalam wilayah administratifnya.

\section{Insentif Persaingan Tidak Sehat}

\section{Lingkup Monopoli Ketenagalis- trikan}

Pembatasan kewenangan bagi PLN konsisten dengan transformasi bentuk BUMN-nya yang tadinya merupakan Perusahaan Umum (Perum) dengan misi pelayanan masyarakat menjadi Perusahaan Perseroan ${ }^{41}$ dengan tujuan utamanya mendapatkan laba sebagaimana layaknya perseroan lain, meskipun sahamnya dimiliki oleh Negara. Sejak saat itu, PLN diperlakukan sebagai korporasi biasa dengan pengecualian bahwa PLN menerima penugasan dari Pemerintah (ESDM) untuk menyelenggarakan pengusahaan tenaga listrik untuk kepentingan umum. ${ }^{42}$ Namun demikian, penugasan berdasarkan Undang-Undang Ketenagalistrikan tidak menutup kemungkinan adanya penyedia tenaga listrik swasta seperti terlihat dengan maraknya skema IPP yang kemudian menjual tenaga listrik yang dihasilkan ke PLN. UndangUndang Ketenagalistrikan Pasal 4 ayat (2) secara jelas membuka kemungkinan tersebut, seperti ditegaskan kembali dalam Putusan Mahkamah Konstitusi Republik Indonesia Nomor 111/PUUXIII/2015 bahwa pelaksanaan kegiatan usaha penyediaan tenaga listrik dapat dilakukan oleh swasta sepanjang tidak diartikan adanya erosi terhadap monopoli Negara terhadap bidang usaha penyediaan tenaga listrik. ${ }^{43}$

Monopoli ini diatur dengan Undangundang dan dapat diselenggarakan oleh Pemerintah yang dapat menunjuk Badan Usaha Milik Negara yang bidang usaha-

${ }^{41}$ Indonesia, Pengalihan Bentuk Perusahaan Umum (Perum) Listrik Negara Menjadi Perusahaan Perseroan (Persero), Peraturan Pemerintah No. 23 Tahun 1994, LN No. 34 Tahun 1999, Pasal 2 (penekanan frasa oleh penulis):

“Maksud dan tujuan Perusahaan Perseroan (PERSERO) sebagaimana dimaksud dalam Pasal 1 adalah:

Menyediakan tenaga listrik bagi kepentingan umum dan sekaligus memupuk keuntungan berdasarkan prinsip pengelolaan Perusahaan;"

${ }^{42}$ Rujuk pada bagian III.B.1. Kedudukan dan Fungsi PLN sebagai Pemberi Izin di atas.

${ }^{43}$ Dalam pertimbangannya, Mahkamah mengutip putusannya terdahulu (Putusan Nomor 001021-022/PUU-I/2003) dalam membenarkan akses kepada swasta dalam pengusahaan ketenagalistrikan yang pendapatnya antara lain berbunyi sebagai berikut:

"Dengan demikian, Mahkamah berpendapat, ketentuan Pasal 33 UUD 1945 tidaklah menolak privatisasi, sepanjang privatisasi itu tidak meniadakan penguasaan oleh negara c.q. Pemerintah sebagai penentu utama kebijakan usaha dalam cabang produksi yang penting bagi negara dan/atau menguasai hajat hidup orang banyak. Pasal 33 UUD 1945 juga tidak menolak ide kompetisi di antara para pelaku usaha, sepanjang kompetisi itu tidak 
nya sesuai. ${ }^{44}$ Namun demikian, berdasarkan penjelasan Pasal 51 Undang-undang Nomor 5 Tahun 1999 Tentang Larangan Praktik Monopoli dan Persaingan Usaha Tidak Sehat (Undang-undang Persaingan Usaha), pengecualian terhadap BUMN dari larangan monopoli tidak dimaksudkan untuk melarang adanya kompetisi dari kalangan swasta, bahkan pelaku usaha asing, melainkan untuk memastikan terpenuhinya kebutuhan pokok bagi seluruh masyarakat. Pengecualian terhadap larangan monopoli yang diberikan kepada negara untuk dilaksanakan oleh BUMN harus dilakukan secara efisien serta tidak mengakibatkan praktik monopoli dan atau persaingan usaha tidak sehat. ${ }^{45}$

\section{Entry Barrier bagi PLTS Atap dan Kewenangan PLN}

Permen ESDM terkait Penggunaan Sistem PLTS Atap oleh Konsumen
PT PLN telah melanggar prinsip anti monopoli karena peraturan tersebut secara efektif memberlakukan larangan masuk (entry barrier) bagi usaha swasta - termasuk kecil dan menengah - dalam pengadaan PLTS Atap dengan mengharuskan adanya perizinan dari PLN. Pun diizinkan oleh PLN, kapasitas terpasang PLTS Atap tidak boleh melebihi kapasitas terpasang PLN pada fasilitas pelanggan yang bersangkutan. ${ }^{46}$ Tidak terdapat alasan teknis mengapa larangan ini diberlakukan karena prinsip dari prosumen (produsen-konsumen sebagaimana dijelaskan sebagai visi Listrik 4.0 Pemerintah dalam RUKN 2019-2038) ${ }^{47}$ memang menghendaki adanya prinsip jual beli tenaga listrik antar konsumen.

PLTS Atap pada umumnya dibangun untuk kepentingan sendiri. Asumsi bahwa PLTS Atap yang terhubung kepada jaringan distribusi (grid) PLN akan

meniadakan penguasaan oleh negara yang mencakup kekuasaan mengatur (regelendaad), mengurus (bertuursdaad), mengelola (beheersdaad), dan mengawasi (toezichthoudensdaad) cabang-cabang produksi yang penting bagi negara dan/atau yang menguasai hajat hidup orang banyak untuk tujuan sebesar-besarnya kemakmuran rakyat."

${ }^{44}$ Indonesia, Larangan Praktek Monopoli dan Persaingan Usaha Tidak Sehat, UU No. 5 Tahun 1999, LN No. 3 Tahun 1999, TLN No. 3817, Pasal 51:

"Monopoli dan atau pemusatan kegiatan yang berkaitan dengan produksi dan atau pemasaran barang dan atau jasa yang menguasai hajat hidup orang banyak serta cabang-cabang produksi yang penting bagi negara diatur dengan Undang-undang dan diselenggarakan oleh Badan Usaha Milik Negara dan atau badan atau lembaga yang dibentuk atau ditunjuk oleh Pemerintah."

${ }^{45}$ Indonesia, Komisi Pengawas Persaingan Usaha, Pedoman Pelaksanaan Ketentuan Pasal 51 Undang-Undang No. 5 Tahun 1999 Tentang Larangan Praktek Monopoli dan Persaingan Usaha Tidak Sehat, Peraturan No. 3 Tahun 2010. Praktik monopoli sendiri diartikan oleh Undang-Undang Persaingan Usaha sebagai pemusatan kekuatan ekonomi oleh satu atau lebih pelaku usaha yang mengakibatkan dikuasainya produksi dan atau pemasaran atas barang dan atau jasa tertentu sehingga menimbulkan persaingan usaha tidak sehat dan dapat merugikan kepentingan umum. Indonesia, Op. Cit., UndangUndang Persaingan Usaha, Pasal 1.2.

${ }^{46}$ Peraturan ESDM No. 49 Tahun 2018, sebagaimana diubah, Op. Cit., Pasal 5(1).

${ }^{47}$ RUKN, Op. Cit., hlm. 88-89. 
PLN vs Energi Terbarukan: Peraturan Menteri ESDM Terkait Penggunaan Sistem Pembangkit Listrik Tenaga Surya Atap

diperuntukkan bagi penjualan excess power kepada PLN adalah tidak berdasar. Sebelum Peraturan ESDM No. 49 Tahun 2018, sebagaimana diubah, PLTS Atap bahkan tidak diperbolehkan untuk menjual kelebihan tenaga kepada PLN karena tarifnya belum ditentukan; yang umum terjadi adalah pemilik pembangkit mempergunakan panel surya untuk kepentingan sendiri tanpa perlu meminta izin instalasi. Peran Pemerintah hanya terbatas pada pemberian SLO untuk memastikan kelaikan teknis pembangkit yang bersangkutan dalam hubungannya dengan jaringan PLN yang akan menyuplai cadangan listrik dalam hal intermittent supply (ketidakstabilan tenaga listrik untuk penggunaan konsumen karena PLTS Atap tidak menghasilkan energi secara terus-menerus (continuous supply). ${ }^{48}$ Usaha kemandirian energi ini terancam kelangsungannya karena pemilik harus memperoleh izin sebelum instalasi PLTS Atap apabila masih mau terhubung dengan grid PLN. ${ }^{49}$ Terlebih lagi, ESDM tidak mempertimbangkan konsep PLTS Atap yang bisa menyimpan kelebihan energi seperti dengan sistem penyimpanan dalam baterai untuk kemudian dipergunakan sebagai cadangan saat terjadi intermittent supply atau down time yang artinya PLTS Atap tersebut tidak menghendaki penjualan kelebihan tenaga kepada grid PLN. Ditinjau secara keseluruhan, pemasangan PLTS Atap membawa beragam kesulitan bagi pemiliknya dan mengurangi potensi keekonomian dari investasi besar yang harus dilakukan di muka mengingat harga panel surya dan biaya instalasinya di Indonesia yang masih terbilang mahal.

Apabila dibenarkan adanya entry barrier, Undang-Undang Persaingan Usaha mengharuskan penugasan terhadap BUMN dilakukan secara jelas melalui Undang-undang. ${ }^{50}$ Ditinjau dari Undang-undang Ketenagalistrikan ${ }^{51}$, nyata adanya bahwa penugasan terhadap PLN tidak meliputi pemberian izin untuk PLTS Atap atau pembangkit lain secara

48 PT PLN (Persero), Pedoman Penyambungan Pembangkit Listrik Energi Terbarukan Ke Sistem Distribusi PLN, Keputusan Direksi No. 0357.K/DIR/2014, Tanggal 22 Juli 2014.

49 Peraturan ESDM No. 49 Tahun 2018, sebagaimana diubah dalam Peraturan ESDM Nomor 13 Tahun 2019 juga menetapkan persyaratan baru kepada pemilik PLTS Atap yang tidak terkoneksi dengan PLN (off-grid) untuk menyampaikan laporan kepada Dirjen EBTKE (Pasal 15(2). Pemilik PLTS Atap sektor industri yang terhubung dengan PLN akan dikenakan pembayaran khusus berupa capacity charge bagi pemakaian listrik PLN untuk menutupi defisit tenaga listrik, terlepas apakah fasilitas yang bersangkutan hendak menjual excess power-nya kepada PLN (Pasal 14(2).

${ }^{50}$ Indonesia, Komisi Pengawas Persaingan Usaha, Op. Cit., Bab II Unsur-Unsur Dalam Pasal 51 UU Nomor 5 Tahun 199 dan Penjabarannya, unsur (4) Diatur dengan Undang-undang, yang antara lain menyatakan bahwa monopoli dalam konteks Pasal 51 Undang-Undang Persaingan Usaha "...hanya dapat dilakukan setelah diatur terlebih dahulu dalam bentuk undang-undang (bukan peraturan perundang-undangan di bawah undang-undang)." (Penekanan frasa oleh penulis.)

${ }^{51}$ Rujuk pada bagian III.B.1. Kedudukan dan Fungsi PLN sebagai Pemberi Izin diatas. 
umum sehingga perlu dipertanyakan apakah pengecualian dari penerapan prinsip anti monopoli berdasarkan Pasal 51 Undang-undang Persaingan Usaha dapat dibenarkan dalam konteks ini dan apakah Undang-undang Persaingan Usaha membenarkan adanya penugasan dalam bidang perizinan karena wewenang ini tidak termasuk lingkup pengusahaan sebagaimana dimaksudkan Pasal 51 Undang-undang Persaingan Usaha.

\section{Konflik Kepentingan PLN dan Diskriminasi Tarif}

Absen adanya pengecualian yang sah dari larangan anti monopoli dalam lingkup Pasal 51 Undang-undang Persaingan Usaha, wewenang PLN dalam Peraturan ESDM tersebut dapat ditafsirkan sebagai konflik kepentingan. Di satu sisi, PLN adalah pelaku usaha penyediaan tenaga listrik yang memegang IUPTL sebagaimana layaknya usaha pembangkit lain yang mencari laba, namun di lain pihak PLN diberi wewenang untuk memutuskan apakah pihak lain dibolehkan untuk membangun PLTS Atap yang berpotensi mengurangi pendapatan PLN. Tidaklah sulit membayangkan suatu skenario, di mana PLN yang tujuan utamanya men- dapat laba, tidak memberi izin pendirian PLTS Atap kepada kalangan usaha swasta atau individu karena akan mengurangi porsi penerimaan tarif listrik PLN yang merupakan sumber utama pendapatannya. ${ }^{52}$ Tendensi atas skenario tersebut tampak dalam bagian pertimbangan Permen ESDM tersebut yang menyatakan bahwa tujuan utama PLTS Atap adalah untuk penghematan pembayaran tenaga listrik bagi konsumen PLN. Betapa tidak lazimnya bahwa ESDM dapat berpraduga motivasi individu atau pelaku usaha dalam memutuskan untuk memiliki PLTS Atap; khususnya praduga ini menyampingkan motivasi pelestarian lingkungan yang sejatinya utama dalam pengembangan PLTS. ${ }^{53}$ Dengan demikian PLN dalam mempertimbangkan permohonan izin akan bias terhadap segi keekonomian dari PLTS Atap, termasuk apakah PLTS yang bersangkutan akan menggantikan kebutuhan konsumen tersebut terhadap listrik PLN. Hal ini tidak saja bertentangan dengan prinsip Undang-undang Persaingan Usaha namun juga Undang-undang Ketenagalistrikan yang tidak menghendaki PLN menjadi satu-satunya pelaku usaha pengadaan listrik. $^{54}$

\footnotetext{
52 PT PLN (Persero), Laporan Keuangan Konsolidasian Untuk Tahun-tahun yang Berakhir pada Tanggal 31 Desember 2018 dan 2017, hlm. 4 menyatakan bahwa 96\% pendapatan PLN berasal dari pembayaran tarif listrik pelanggan. PLTS Atap yang di-swasembadakan oleh pelanggan PLN tentunya akan mengurangi ketergantungan terhadap listrik yang disediakan oleh PLN dan pada akhirnya juga mengurangi porsi pendapatan tersebut.

${ }^{53}$ Peraturan Menteri ESDM No. 49 Tahun 2018, Op. Cit., Pasal 2.

${ }^{54}$ Undang-Undang Ketenagalistrikan, Op. Cit., Pasal 4 (2). Indonesia, Komisi Pengawas Persaingan Usaha, Op. Cit., Bab III Simulasi Kasus Yang Terkait Dengan Pasal 51 UU Nomor 5 Tahun 1999, B. Kasus
} 
PLN vs Energi Terbarukan: Peraturan Menteri ESDM Terkait Penggunaan Sistem Pembangkit Listrik Tenaga Surya Atap

Selanjutnya dapat dilihat bahwa diskriminasi terhadap PLTS Atap juga tampak dalam aspek komersial pemasangan PLTS Atap. Pertama, penentuan besaran excess power yang diterima oleh PLN dan tarif bagi PLTS Atap dalam Peraturan ESDM tersebut. PLN hanya akan memperhitungkan $65 \%$ dari nilai kWh ekspor yang dihasilkan PLTS Atap sebagai excess power, yang kemudian selisihnya dengan penggunaan listrik dari PLN oleh pelanggan yang bersangkutan (kWh impor) yang akan dibeli oleh PLN. Kemudian bagi PLTS Atap yang dipasang oleh konsumen level industri, pengenaan capacity charge juga akan menjadi beban khusus bagi pelanggan. Lagilagi pertimbangan yang diberikan adalah karena PLTS Atap hanya digunakan untuk menghemat pembayaran rekening pelanggan. Ironis bahwa kebijakan ini bertentangan dengan perintah khusus Undang-undang Ketenagalistrikan yang mengharuskan keutamaan penggunaan energi terbarukan.

\section{Penutup}

Dalam usaha memenuhi target Pemerintah untuk meningkatkan level bauran energi terbarukan, khususnya tenaga surya yang tersedia secara masif dan gratis, kebijakan yang terkandung dalam Permen ESDM terkait Penggunaan Sistem PLTS Atap oleh Konsumen PT PLN harus ditinjau ulang. Insentif, atau setidaknya perlakuan yang non-diskriminatif, harus diberikan kepada pihak yang hendak beralih ke PLTS Atap dan berkontribusi pada keberlangsungan tenaga ramah lingkungan.

Bentuk dan isi peraturan yang diterbitkan juga harus memperhatikan kaidah pembentukan peraturan perundang-undangan untuk menghindari pertentangan dengan instrumen hukum lain, termasuk peraturan yang tingkatnya lebih tinggi, baik dalam kandungan materi yang sesuai ataupun pencabutan wewenang khusus bagi pemerintah daerah berdasarkan Undang-undang dan Konstitusi. Keberadaan PLN hanya sebagai BUMN penerima mandat usaha penyelenggaraan ketenagalistrikan tidak bisa diartikan melebihi wewenangnya dan lantas diberikan kuasa perizinan dan menimbulkan berbagai potensi perilaku persaingan usaha tidak sehat.

Monopoli yang mengarah pada Praktek Monopoli dan atau Persaingan Usaha Tidak Sehat yang membahas penunjukan langsung oleh BUMN menyatakan bahwa tindakan yang dilakukan oleh pemegang hak monopoli yang bertentangan dengan prinsip-prinsip persaingan usaha yang sehat tidak dikecualikan, termasuk ketika terjadi potensi tindakan yang menghambat persaingan sebagaimana dimaksud dalam Pasal 19 Undang-Undang Persaingan Usaha (mengenai penguasaan pasar). 


\section{DAFTAR PUSTAKA}

\section{Peraturan Perundang-Undangan}

Indonesia. Undang-Undang Dasar Negara 1945.

. Larangan Praktek Monopoli dan Persaingan Usaha Tidak Sehat, UU No. 5 Tahun 1999, LN No. 3 Tahun 1999, TLN No. 3817.

Komisi Pengawas Persaingan Usaha, Peraturan tentang Pedoman Pelaksanaan Ketentuan Pasal 51 Undang-Undang No. 5 Tahun 1999 Tentang Larangan Praktek Monopoli dan Persaingan Usaha Tidak Sehat, No. 3 Tahun 2010.

. Undang-Undang Ketenagalistrikan, UU No. 30 Tahun 2009, LN No. 133 Tahun 2009, TLN No. 5052.

- Undang-Undang Pembentukan Peraturan Perundang-undangan, UU No. 12 Tahun 2011, LN No. 82 Tahun 2011, TLN No. 5234.

. Undang-Undang tentang Perubahan atas Undang-Undang Nomor 12 Tahun 2011 tentang Pembentukan Peraturan Perundang-undangan, UU No. 15 Tahun 2019, LN No. 183 Tahun 2019, TLN No. 6398.

. Undang-Undang Pemerintahan Daerah, UU No. 23 Tahun 2014, LN No. 244 Tahun 2014, TLN No. 5587.

Pengalihan Bentuk Perusahaan Umum (Perum) Listrik Negara Menjadi Perusahaan Perseroan (Persero), PP No. 23 Tahun 1994, LN No. 34 Tahun 1999.
Kegiatan Usaha Penyediaan Tenaga Listrik, PP No. 14 Tahun 2012, LN No. 28 Tahun 2012, TLN 5281.

. Menteri Energi dan Sumber Daya Mineral, Peraturan tentang Kapasitas Pembangkit Tenaga Listrik Untuk Kepentingan Sendiri Yang Dilaksanakan Berdasarkan Izin Operasi, No. 29 Tahun 2012, BN No. 1255 Tahun 2012.

Menteri Energi dan Sumber Daya Mineral, Peraturan Menteri Energi dan Sumber Daya Mineral tentang Pemanfaatan Sumber Energi Terbarukan Untuk Penyediaan Tenaga Listrik, No. 50 Tahun 2017, BN No. 1107 Tahun 2017.

. Menteri Energi dan Sumber Daya Mineral, Peraturan Menteri Energi dan Sumber Daya Mineral tentang Penggunaan Sistem Pembangkit Listrik Tenaga Surya Atap oleh Konsumen PT Perusahaan Listrik Negara (Persero), Peraturan No. 49 Tahun 2018, BN No. 1525 Tahun 2018.

. Menteri Energi dan Sumber Daya Mineral, Peraturan Menteri Energi dan Sumber Daya Mineral tentang Perubahan atas Peraturan Menteri Energi dan Sumber Daya Mineral Nomor 49 Tahun 2018 tentang Penggunaan Sistem Pembangkit Listrik Tenaga Surya Atap oleh Konsumen PT Perusahaan Listrik Negara (Persero), Peraturan No. 13 Tahun 2019, BN No. 1020 Tahun 2019.

. Menteri Energi dan Sumber Daya Mineral, Peraturan Menteri Energi 
PLN vs Energi Terbarukan: Peraturan Menteri ESDM Terkait Penggunaan Sistem Pembangkit Listrik Tenaga Surya Atap

dan Sumber Daya Mineral tentang Perubahan Kedua atas Peraturan Menteri Energi dan Sumber Daya Mineral Nomor 49 Tahun 2018 tentang Penggunaan Sistem Pembangkit Listrik Tenaga Surya Atap oleh Konsumen PT Perusahaan Listrik Negara (Persero), Peraturan No. 16 Tahun 2019, BN No. 1179 Tahun 2019.

Menteri Energi dan Sumber Daya Mineral, Keputusan Menteri Energi dan Sumber Daya Mineral tentang Pengesahan Rencana Usaha Penyediaan Tenaga Listrik PT Perusahaan Listrik Negara (Persero) Tahun 2019 Sampai Dengan 2028, No. 39 K/20/ MEM/2019.

Menteri Energi dan Sumber Daya Mineral, Keputusan Menteri Energi dan Sumber Daya Mineral tentang Rencana Umum Ketenagalistrikan Nasional Tahun 2019 Sampai Dengan 2038, No. 143 K/20/MEM/2019 Tahun 2019.

Daerah Khusus Ibukota Jakarta. Penugasan kepada Perseroan Terbatas Jakarta Propertindo (Perusahaan Daerah) dalam Penyelenggaraan Fasilitas Pengolahan Sampah Antara di Dalam Kota, Peraturan No. 65 Tahun 2019, Berita Daerah Nomor 73004 Tahun 2019.

\section{Putusan pengadilan}

Mahkamah Konstitusi, Putusan No. 111/ PUU-XIII/2015.

Mahkamah Konstitusi, Putusan No. 11/ PUU-XIV/2016.

\section{Artikel Jurnal/Media Massa}

Aditya, Zaka Firma dan M. Reza Winata. Rekonstruksi Hierarki Peraturan Perundang-undangan di Indonesia, Negara Hukum Membangun Hukum untuk Keadilan dan Kesejahteraan, Vol. 9, No. 1, Juni 2018.

Denny, Septian. "Potensi Energi Tenaga Surya RI 10 Kali Lebih Besar dari Jerman," https://www.liputan6.com/ bisnis/read/2493191/potensienergi-tenaga-surya-ri-10-kali-lebihbesar-dari-jerman? u tm expid=.9Z4i5ypGQeGiS7w9arwTvQ.0\&utm_referrer $=$ ht t ps\%3A\%2F\%2Fwww.liputan6. c o m \% $2 \mathrm{Fbisnis} \% 2 \mathrm{Fre}$ ad $\% 2$ F2493191\%2Fpotensi-energitenaga-surya-ri-10-kali-lebih-besardari-jerman, diakses tanggal 14 Agustus 2019.

IDZ/BIR. "Energi Terbarukan Bisa Bikin Pemerintah Hemat Puluhan Triliun," https://www.cnnindonesia.com/ e $\mathrm{k} \quad \mathrm{O} \quad \mathrm{n} \quad \mathrm{o}$ mi/20190424095301-85-389098/ energi-terbarukan-bisa-bikin-pemerintah-hemat-puluhan-triliun, diakses tanggal 14 Agustus 2019.

MTH. "Pasang PLTS Atap, Tagihan Listrik Lebih Hemat," https://kominfo. go.id/index.php/content/detail/20547/pasang-plts-atap-tagihanlistrik-lebih-hemat/0/artikel_gpr, diakses tanggal 31 Agustus 2019.

Pamudji/FER. "Konsep Bangunan Hijau Butuh Insentif Pemerintah," https:// www.beritasatu.com/interi- 
or/154113-konsep-bangunan-hijaubutuh-insentif-pemerintah.html, diakses tanggal 31 Agustus 2019.

Rahadian, Lalu. "Ini 10 PLTU yang Berpotensi Sumbang Polusi Udara Jakarta," https://jakarta.bisnis.com/ read/20190716/77/1124981/ini10-pltu-yang-berpotensi-sumbangpolusi-udara-jakarta, diakses tanggal 17 Agustus 2019.

Sulaiman, Stefanno Reinard. “New solar panel regulation discourages public use," https://www.thejakartapost. com/news/2019/02/22/new-solarpanel-regulation-discourages-public-use.html, diakses tanggal 16 Agustus 2019.

Tim Komunikasi ESDM. “Narasi Tunggal: Pasang PLTS Atap, Tagihan Listrik Lebih Hemat," https://www. esdm.go.id/id/media-center/arsipberita/narasi-tunggal-pasang-pltsatap-tagihan-listrik-lebih-hemat, diakses tanggal 31 Agustus 2019.

Thomas, Jason. "Indonesian Dull Solar Sector," https://theaseanpost.com/ article/indonesias-dull-solar-sector, diakses tanggal 14 Agustus 2019.

Widyaningsih, Grita Anindarini. "Membedah Kebijakan Perencanaan Ketenagalistrikan di Indonesia," Jurnal Hukum Lingkungan Indonesia, Vol. 5, No. 1, Oktober 2018.

\section{Lain-Lain}

PT PLN (Persero). “Laporan Keuangan Konsolidasian Untuk Tahun-tahun yang Berakhir pada Tanggal 31 De- sember 2018 dan 2017".

PT PLN (Persero). “Pedoman Penyambungan Pembangkit Listrik Energi Terbarukan Ke Sistem Distribusi PLN," Keputusan Direksi No. 0357.K/DIR/2014, Tanggal 22 Juli 2014.

PT PLN (Persero). "Statistik PLN 2017," Sekretariat Perusahaan PLN, https:// www.pln.co.id/statics/uploads/2018/06/Laporan-StatistikPLN-2017-Indonesia.pdf, diakses pada 25 Agustus 2019.

Robertsson, Stefan. "Southeast Asian Solar: Market Outlook and Policy Overview," The Lantau Group, 31 Agustus 2017, https://www.lantaugroup. com/files/ppt_pgen17_sr.pdf, diakses tanggal 15 Agustus 2019. 